\title{
Pengembangan model chef and cooking pada pembelajaran IPS
}

\author{
Wahyu Purwanto ${ }^{\text {a, }}$ 1* $^{*}$ \\ ${ }^{a}$ SMPN 3 Yosowilangun, Lumajang Jawa Timur, Indonesia \\ ${ }^{1}$ wahyupurwanto1986@gmail.com* \\ *korespondensi penulis
}

\begin{tabular}{ll}
\hline Informasi artikel & ABSTRAK \\
\hline Kata kunci: & Aktivitas belajar rendah merupakan masalah yang seringkali terjadi dalam \\
aktivitas belajar; & pembelajaran IPS. Chef and Cooking (C\&C) adalah sebuah model pembelajaran \\
IPS; & dimana peserta didik dianalogikan sebagai sekelompok chef (koki) dalam arena \\
Metode chef and & perlombaan yang melakukan aktivitas cooking (memecahkan permasalahan) dari \\
cooking & bahan yang telah disediakan, dan menghasilkan sebuah menu (laporan kelompok) \\
& dengan melibatkan inovasi dan kreativitasnya. Metode dalam penelitian ini adalah \\
& Research and Development $(R \& D)$ menggunakan model Borg and Gall. Hasil \\
& penelitian menunjukkan skor validasi 83,80. Uji kelayakan menunjukkan peningkatan \\
& aktivitas siswa dalam belajar IPS dari $62,96 \%$ menjadi 82,00\%. Oleh karena itu, \\
& pengembangan model $C \& C$ layak untuk diterapkan sebagai alternatif untuk mengatasi \\
& masalah yang terjadi dalam pembelajaran IPS.
\end{tabular}

Keywords: learning activity; social studies; chef and cooking method,

\begin{abstract}
Student low activity is a problem that occurs in Social Studies learning. Learning models must be developed to increase their participation. Chef and Cooking $(C \& C)$ is a learning model in which learners are playing as a group of Chefs in a competition. They perform Cooking activities (problems solving) of the material provided and produces a menu (report group). It is involving innovation and creativity. The study based on Research and Development $(R \& D)$ method that applies Borg and Gall model. The results 83.80 validation score. the feasibility test showed an increase in student activity in Social Studies learning from $62.96 \%$ to $82.00 \%$. Therefore, the development of the $C \& C$ model is feasible to be applied as an alternative to overcome the problems that occur in Social Studies learning.
\end{abstract}

Copyright $\odot 2018$ Wahyu Purwanto. All Right Reserved

\section{PENDAHULUAN}

Era global membawa konsekuensi pada kehidupan manusia yang harus mampu berkomunikasi baik secara lokal, regional, maupun internasional. Ilmu Pengetahuan Sosial (IPS) memegang peranan penting dalam dunia pendidikan untuk mengantar siswa mengarungi era global tersebut. Perlu diingat bahwa tujuan IPS adalah mempersiapkan generasi bangsa menjadi warga negara yang baik dalam komunitas yang demokratis dan keberagaman budaya
(Schneider et al., 1994). Akan tetapi, dalam penerapan pembelajaran IPS terdapat tantangan yang sering dijumpai di sekolah. Berdasarkan wawancara dengan siswa pada 9 Januari 2014 di SMPN 3 Yosowilangun diperoleh data sebagai berikut; sebanyak $64 \%$ siswa tidak menyukai, dan hanya $36 \%$ menyukai pelajaran IPS. Alasan mayoritas siswa tidak menyukai yaitu, $32 \%$ mengatakan materi pelajaran yang terlalu banyak, 22\% tidak menyukai pelajaran hafalan, dan $10 \%$ pembelajaran yang membosankan. Persepsi 
siswa terhadap pelajaran IPS tersebut membawa dampak pada tingkat rendahnya keaktifan pada aktivitas pembelajaran.

Hal tersebut senada dengan penelitian Dewi \& Amirudin (2016) bahwa hanya 37,04 $\%$ siswa aktif, dan $62,96 \%$ siswa melakukan aktivitas di luar konteks pembelajaran IPS. Indikator rendahnya keaktifan tersebut dapat dilihat dari sikap pasif siswa dalam bertanya, siswa tertentu yang aktif dalam diskusi, dan kurangnya rasa tanggung jawab terhadap tugas yang diterima. Penelitian Waty, Rustini, \& Sundari (2015), bahwa dalam pembelajaran IPS peserta didik masih kurang aktif dan komunikasi yang terjadi hanya satu arah.

Berbagai masalah dalam pembelajaran IPS berdampak munculnya persepsi siswa pada mata pelajaran. Bahwa IPS adalah mata pelajaran yang berisi hafalan, materi yang terlalu banyak, sampai munculnya sikap tidak menyukai pelajaran tersebut. Sedangkan faktor pendampingnya yaitu, masih kurangnya sarana dan prasarana sumber belajar pendukung, sehingga peserta didik hanya mengandalkan buku teks sebagai sumber satu-satunya. Sumber belajar internet dan media audio visual seringkali terkendala keterbatasan jumlah alat pelajaran yang tersedia, seperti halnya $L C D$ projector.

Oleh karena itu, untuk membangkitkan aktivitas belajar siswa terhadap pembelajaran IPS sangat dibutuhkan sebuah pembelajaran yang aktif, kreatif, efektif, dan menyenangkan
(PAKEM). Akronim PAKEM pada mulanya dikembangkan dari istilah AJEL (Active Joyful and Effective Learning) dengan landasan teorinya pembelajaran aktif (Asmani, 2013; Mayangsari, 2014). Modelmodel pembelajaran yang menarik dan menyenangkan sudah tentu banyak. Akan tetapi sebuah model pembelajaran yang mengintegrasikan sesuatu hal yang disukai siswa pada aktivitas pembelajaran, tentu akan meningkatkan aktivitas belajarnya.

Ide pengembangan model Chef and Cooking $(C \& C)$ muncul di saat pembelajaran yang dilakukan belum dapat menarik minat dan aktivitas belajar IPS peserta didik. Berdasarkan pengalaman mengajar IPS di SMPN 3 Yosowilangun, penerapan modelmodel pembelajaran lain seperti PBL atau cooperative learning belum berhasil secara maksimal. Peserta didik cenderung asyik dalam tahapan model, tetapi pemahaman akan tujuan pembelajaran belum tercapai. Misalnya, penerapan model TSTS (Two Stay Two Stray) dalam pembelajaran IPS, peserta didik sangat asyik dalam berpindah-pindah saja. Ketidakseriusan dalam belajar menjadikan pembelajaran hanya asyik dan menyenangkan, akan tetapi aktivitas belajar hanya milik peserta didik tertentu. Masih banyak peserta didik yang berperan sebagai anggota pasif dalam proses diskusi kelompok.

Berdasarkan beberapa pengalaman penerapan pembelajaran di atas, guru perlu melakukan inovasi yang mengakomodasi 
kemampuan dan kemauan siswa. Salah satu upaya yang dapat dilakukan adalah memasukkan unsur minat intrinsik yang dimiliki oleh siswa. Cara paling efektif membangkitkan minat pada suatu objek adalah dengan menggunakan minat-minat peserta didik yang telah ada (Slameto, 2013). Sehingga, aktivitas dan keseriusan siswa dalam pembelajaran lebih maksimal.

Atas dasar analisis kebutuhan dan realita pembelajaran, perlu untuk mengembangkan sebuah model pembelajaran yang dibutuhkan baik oleh kurikulum maupun kebutuhan peserta didik. Siswa membutuhkan sebuah model pembelajaran yang juga mengakomodasi minat dan rasa suka terhadap sesuatu hal yang digemarinya. Sebuah model pembelajaran yang menggabungkan antara pembelajaran yang aktif dan menyenangkan dengan konsep salah satu acara televisi yang disukai siswa. Konsep acara televisi tersebut terintegrasi dalam langkah-langkah pembelajaran. Hasil pengembangan tersebut dinamakan model Chef and Cooking $(C \& C)$.

$C \& C$ adalah sebuah model pembelajaran siswa dianalogikan sebagai sekelompok chef (koki) dalam arena perlombaan yang melakukan aktivitas cooking (memecahkan permasalahan) dari bahan olahan yang telah disediakan, dan menghasilkan sebuah menu (laporan kelompok) dengan melibatkan inovasi dan kreativitasnya. Penerapan model pembelajaran ini diharapkan dapat meningkatkan aktivitas belajar siswa, khususnya dalam pembelajaran IPS. Sehingga pada akhirnya tujuan IPS dapat dicapai untuk kehidupan siswa pada masa mendatang. Perlu diingat bahwa keutamaan hakikat pendidikan adalah untuk mengantisipasi kehidupan pada masa yang akan datang (Hariyono, 1995).

\section{METODE}

Metode dalam penelitian ini menggunakan pengembangan atau Research and Development. Penelitian pengembangan yang dilakukan menggunakan model Borg and Gall (2003). Salah satu alasan pemilihan model ini, yaitu langkah-langkah penelitian yang lebih rinci sehingga validitas dan kejelasan hasil penelitian lebih maksimal (Ariyanti, Wahyono, \& Haryono, 2016). Langkah-langkah penelitian pengembangan terdiri atas 10 tahapan pengembangan. Secara rinci dapat dijabarkan sebagai berikut; 1) studi pendahuluan; 2) perencanaan pengembangan; 3) pengembangan awal; 4) uji coba awal; 5) revisi produk; 6) uji lapangan terbatas; 7) revisi produk hasil uji lapangan; 8) uji kelayakan; 9) revisi produk akhir; dan 10) diseminasi dan penerapan (Gall et al., 2003).

Uji coba awal dilakukan oleh ahli dengan tujuan mendapatkan masukan sekaligus meminimalkan kesalahan dalam pengembangan sebuah model pembelajaran. Sedangkan uji coba lapangan menggunakan penelitian tindakan kelas di SMPN 3 Yosowilangun. Kriteria kelayakan produk adalah sebagai berikut. 
Tabel 1. Kriteria Kelayakan

\begin{tabular}{|c|c|c|c|}
\hline \multirow[b]{2}{*}{ Skor } & \multicolumn{2}{|c|}{ Hasil Uji } & \multirow[b]{2}{*}{$\begin{array}{l}\text { Tindak } \\
\text { lanjut }\end{array}$} \\
\hline & Persentase & $\begin{array}{c}\text { Kualifi } \\
\text { kasi }\end{array}$ & \\
\hline 4 & $85-100$ & $\begin{array}{l}\text { Sangat } \\
\text { Layak }\end{array}$ & Implementasi \\
\hline 3 & $75-84$ & Layak & $\begin{array}{l}\text { Implementasi } \\
\text { dengan } \\
\text { sedikit revisi }\end{array}$ \\
\hline 2 & $55-74$ & $\begin{array}{l}\text { Cukup } \\
\text { Layak }\end{array}$ & $\begin{array}{l}\text { Revisi sesuai } \\
\text { catatan ahli }\end{array}$ \\
\hline 1 & $<55 \%$ & $\begin{array}{l}\text { Kurang } \\
\text { Layak }\end{array}$ & $\begin{array}{c}\text { Revisi } \\
\text { dengan } \\
\text { pengubahan } \\
\end{array}$ \\
\hline
\end{tabular}

Sumber: Sugiyono (2012)

Kriteria ahli dalam penelitian ini yaitu; guru profesional bersertifikat pendidik, guru inti mata pelajaran IPS, dan pengalaman masa kerja lebih dari 10 tahun, dan minimal berpangkat guru pembina. Selain itu juga berlatar belakang pendidikan minimal magister.

\section{HASIL DAN PEMBAHASAN}

\section{Hasil Pengembangan Produk}

$C \& C$ adalah sebuah model pembelajaran dimana peserta didik dianalogikan sebagai sekelompok chef (koki) dalam arena perlombaan yang melakukan aktivitas cooking (memecahkan permasalahan) dari bahan olahan yang telah disediakan, dan menghasilkan sebuah mеnu (laporan kelompok) dengan melibatkan inovasi dan kreativitasnya. Penerapan model pembelajaran ini diharapkan dapat meningkatkan aktivitas belajar peserta didik, khususnya dalam pembelajaran IPS. Sehingga pada akhirnya tujuan IPS dapat dicapai untuk kehidupan peserta didik pada masa mendatang.

Penerapan model $C \& C$ dimulai dengan kelas dibentuk menjadi beberapa kelompok yang beranggotakan 5-6 siswa. Langkah berikutnya yaitu ketua kelompok (Master Chef) mendapat pengarahan dari guru terkait tugas yang dibuat dan pembagian bahan olahan. Pada saat bersamaan anggota kelompok (Chef) merumuskan pertanyaan di setiap kelompoknya.

Langkah selanjutnya yaitu, ketua kelompok (Master Chef) kembali pada kelompok masing-masing dan memberikan penjelasan permasalahan yang harus dikerjakan dengan bahan yang tersedia. Guru membimbing setiap kelompok untuk menghasilkan sebuah pertanyaan yang sesuai dengan indikator pembelajaran. Rumusan pertanyaan dituliskan pada secarik kertas dan dibentuk seperti bola dan dilemparkan kepada kelompok lain. Setiap kelompok menerima pertanyaan dari kelompok lain dan mendiskusikan pemecahan permasalahan (cooking): a) memecahkan masalah yang dibawa ketua kelompok (Master Chef), dan b) memecahkan pertanyaan dari kelompok lain.

Selanjutnya, pelaksanaan diskusi dan penghasilan produk dari pemecahan permasalahan (cooking) dibatasi oleh waktu. Secara undian kelompok mempresentasikan produk hasil diskusi dari pemecahan permasalahan (menu). Guru bersama siswa memberi simpulan hasil diskusi. 
Penerapan model pembelajaran $C \& C$ ini membutuhkan beberapa bahan pendukung. Pendukung pertama, yaitu topi chef. Topi koki merupakan ciri khas model pembelajaran ini. Salah satu bahan topi yang paling ekonomis adalah membuat topi dari kertas karton warna putih. Kemudian diberikan pita merah sebagai penghias topi.

Bahan pendukung pembelajaran model $C \& C$ yang kedua, adalah tas belanja. Fungsi dari tas belanja ini adalah untuk menaruh bahan olahan yang akan dijadikan sumber aktivitas peserta didik. Tas belanja yang disediakan harus sesuai dengan jumlah kelompok yang telah dibentuk.

Pendukung ketiga, yaitu kertas kerja dapat berupa kertas flano, manila, atau karton. Akan tetapi untuk mendapatkan hasil lebih indah dan kreatif dari peserta didik, guru dapat menyediakan kertas kerja dari kertas ariston warna.

Bahan pendukung keempat, yaitu alat tulis yang dibutuhkan untuk mendukung proses penerapan pembelajaran model $C \& C$ antara lain; lem, gunting, spidol warna, dan penggaris. Alat-alat tulis tersebut disediakan dalam 1 paket sesuai jumlah kelompok. Kemudian, beberapa alat tulis tersebut diletakkan pada tas belanja yang nantinya akan dibagikan kepada Master Chef (ketua kelompok).

\section{Hasil Uji Kelayakan}

Produk model $C \& C$ ini dikaji dengan menggunakan metode penelitian pengembangan. Penelitian pengembangan yang dilakukan menggunakan model Borg and Gall (2003) melalui sepuluh tahapan pengembangan dengan hasil studi pendahuluan diperoleh data tentang permasalahan pembelajaran IPS selama ini. Sebanyak 64\% siswa tidak menyukai, dan hanya $36 \%$ menyukai pelajaran IPS. Alasan mayoritas siswa tidak menyukai yaitu, $32 \%$ mengatakan materi pelajaran yang terlalu banyak, 22\% tidak menyukai pelajaran hafalan, dan $10 \%$ pembelajaran yang membosankan. Persepsi siswa terhadap pelajaran IPS membawa dampak tingkat rendahnya keaktifan pada aktivitas pembelajaran.

Uji coba awal dilakukan oleh ahli dengan tujuan mendapatkan masukan sekaligus meminimalkan kesalahan dalam pengembangan sebuah model pembelajaran. Selain itu, juga untuk mendapatkan data tentang tingkat kelayakan produk sebuah pengembangan.

Kriteria ahli dalam penelitian ini yaitu; guru profesional bersertifikat pendidik, guru inti mata pelajaran IPS, pendidikan minimal magister, pengalaman masa kerja lebih dari 10 tahun, dan minimal berpangkat guru pembina. Adapun ahli yang bertindak sebagai validator pada penelitian pengembangan ini adalah guru inti IPS di Kabupaten Lumajang yang juga bertindak sebagai Narasumber Nasional.

Uji kelayakan model $C \& C$ dilakukan dengan metode Penelitian Tindakan Kelas 
(PTK). Penelitian tindakan kelas dilakukan untuk mengukur sejauh mana kelayakan produk dengan permasalahan yang terjadi di kelas. Uji kelayakan ini dilakukan pada kelas VII D semester genap tahun ajaran 2014/2015 pada tanggal 9 s/d 16 September 2014. Penelitian berlangsung selama dua siklus. Pelaksanaan penelitian tersebut, peneliti dibantu dua orang observer yang merupakan guru IPS.

Berdasarkan hasil uji kelayakan diperoleh data tentang hasil uji kelayakan produk ini pada tabel 2 sebagai berikut.

Tabel 2. Hasil Uji Kelayakan

\begin{tabular}{|c|c|c|c|}
\hline \multirow{2}{*}{ No } & \multirow{2}{*}{ Indikator } & \multicolumn{2}{|c|}{ Skor Persentase } \\
\hline & & Siklus I & Siklus II \\
\hline 1. & $\begin{array}{l}\text { Aktivitas } \\
\text { Siswa }\end{array}$ & $79 \%$ & $86 \%$ \\
\hline 2. & $\begin{array}{l}\text { Respon Siswa } \\
\text { dalam Belajar }\end{array}$ & $68 \%$ & $82 \%$ \\
\hline 3. & $\begin{array}{l}\text { Pelaksanaan } \\
\text { Pembelajaran }\end{array}$ & $71 \%$ & $93 \%$ \\
\hline 4. & $\begin{array}{c}\text { Keterlaksanaan } \\
\text { Model C\&C }\end{array}$ & $65 \%$ & $89 \%$ \\
\hline
\end{tabular}

Berdasarkan tabel di atas diperoleh data bahwa aktivitas siswa pada siklus I mencapai $79 \%$ dan pada siklus II 86\%. Respon siswa dalam belajar IPS pada siklus I mencapai $68 \%$ dan pada siklus II 82\%. Pelaksanaan pembelajaran pada siklus I mencapai $71 \%$ dan pada siklus II 93\%. Sedangkan keterlaksanaan model pembelajaran $C \& C$ pada siklus I mencapai 65\% dan siklus II 89\%.

Tindakan pada siklus I masih terdapat beberapa kendala. Kendala yang terjadi pada siklus I yaitu, pada awalnya pembelajaran terkesan ruwet. Khususnya pada tahap proses penyusunan soal. Siswa terlalu bersemangat dalam melempar bola kertas pertanyaan. Sehingga, bola kertas tidak tepat sasaran. Hambatan kedua, yaitu masih ada beberapa peserta didik dalam kelompok yang tergantung pada Master Chef atau ketua kelompok. Hambatan ketiga, waktu yang dibutuhkan melebihi yang direncanakan. Siswa keasyikan dalam proses menghasilkan karya yang akan dipresentasikan. Waktu belajar lebih tersita untuk kegiatan gunting menggunting bahan olahan.

Atas dasar hambatan pada siklus I tersebut, diambil tindakan sebagai refleksi. Tindakan yang telah dilakukan yaitu, mempersiapkan bahan olahan yang telah digunting. Sehingga siswa tinggal menempel sesuai dengan ide kreatif masing-masing. Selain itu, guru lebih berperan sebagai fasilitator khususnya dalam proses penyusunan pertanyaan dan diskusi kelompok. Penyusunan pertanyaan tetap individu, kemudian Master Chef berhak memilih satu pertanyaan yang dibuat anggotanya. Kemudian Master Chef yang berperan melempar kepada Master Chef kelompok lain. Tindakan ini terbukti lebih efektif pada waktu proses pertukaran pertanyaan pada pembelajaran di siklus II.

Penerapan model ini pernah mendapatkan penghargaan dari Bupati Lumajang pada tahun 2014, sebagai Juara II pembelajaran aktif, kreatif, efektif, dan menyenangkan (PAKEM). Penghargaan tersebut diperoleh 
pada lomba pembelajaran aktif, kreatif, dan menyenangkan dalam rangka Hari Jadi Lumajang (HARJALU) ke 759 yang diselenggarakan oleh Dewan Pendidikan Kabupaten Lumajang. Perlombaan tersebut dengan cara mengirimkan sebuah video pembelajaran di kelas.

\section{Penerapan Model $C \& C$ dalam} Pembelajaran IPS

Berdasarkan data yang diperoleh selama tahapan penelitian, dapat disimpulkan bahwa model pembelajaran $C \& C$ layak untuk diterapkan dalam pembelajaran IPS. Hasil validasi ahli menunjukkan skor 83,80. Artinya model pembelajaran ini dikategorikan layak untuk diterapkan. Berdasarkan kriteria penilaian pengembangan produk, skor $75 \%$ sampai dengan $84 \%$ adalah layak diimplementasikan dengan sedikit revisi (Sugiyono, 2012). Revisi yang disarankan oleh ahli yaitu; a) menambahkan unsur khas chef dalam langkah model pembelajaran, b) media pembelajaran pendukung perlu disempurnakan, dan c) model pembelajaran $C \& C$ layak untuk diimplementasikan dalam pembelajaran setelah direvisi.

Hasil uji lapangan juga menunjukkan bahwa penerapan model $C \& C$ dapat meningkatkan aktivitas belajar IPS peserta didik. Peningkatan itu ditunjukkan pada siklus I, aktivitas peserta didik mencapai $79 \%$. Sedangkan pada siklus II meningkat menjadi 86\%. Secara klasikal model pembelajaran $C \& C$ terbukti dapat meningkatkan aktivitas belajar IPS peserta didik. Hal tersebut senada dengan hasil penelitian Saraswati, Marhaeni, \& Natajaya (2015), bahwa melalui penerapan PAKEM dalam pembelajaran IPS mengakibatkan suasana belajar aktif, kreatif, efektif namun juga menyenangkan, sehingga memudahkan pemahaman konsep-konsep pembelajaran IPS. Indikator dari aktivitas belajar peserta didik dapat dilihat dari keingintahuan terhadap materi, bertanya/menjawab, kerja sama dalam kelompok, aktif dalam diskusi, mengutarakan pendapat, presentasi, membuat laporan pembelajaran, dan menyimpulkan pembelajaran.

Data lain juga menunjukkan bahwa respons peserta didik dalam belajar IPS mengalami peningkatan dari $68 \%$ menjadi $82 \%$. Selain itu, dari sisi penerapan model pembelajaran didapatkan data yaitu peningkatan pelaksanaan pembelajaran dari $71 \%$ menjadi 93\%, dan keterlaksanaan model pembelajaran $C \& C$ dari $65 \%$ menjadi $89 \%$. Salah satu metode pembelajaran yang dapat meningkatkan minat, motivasi, dan hasil belajar siswa adalah pembelajaran yang aktif dan menyenangkan (Nurseto, 2009; Saraswati et al., 2015). Lebih lanjut Barkley (2009) mengatakan bahwa pembelajaran yang aktif dan menyenangkan dapat meningkatkan motivasi untuk terus belajar siswa sepanjang hidupnya.

Penerapan model $C \& C$ terbukti layak untuk diterapkan dalam pembelajaran IPS. 
Siswa dalam pembelajaran model $C \& C$ dituntut untuk belajar bersama sesuai pengalaman yang diperolehnya. Hal ini sejalan dengan pendapat Slameto (2013), bahwa belajar merupakan proses sebuah usaha perubahan tingkah laku seseorang yang diperoleh dari hasil pengalaman interaksi atau aktivitas dengan lingkungannya.

Keunggulan penerapan model $C \& C$ ini, yaitu; 1) mampu meningkatkan aktivitas belajar IPS peserta didik; 2) meningkatkan peran aktif dan komunikasi antar anggota kelompok; 3) kemampuan mengembangkan ide atau gagasan kreatif dalam memecahkan permasalahan; dan 4) mengakomodasi pembelajaran dengan minat peserta didik. Selain itu, proses pembelajaran menggunakan model ini menuntut keaktifan guru sebagai fasilitator dan motivator dalam proses pembelajaran. Aktivitas belajar IPS dapat dilihat dari indikator keingintahuan terhadap materi, bertanya/menjawab, kerja sama dalam kelompok, aktif dalam diskusi, mengutarakan pendapat, presentasi, membuat laporan pembelajaran, dan menyimpulkan pembelajaran.

Pembelajaran dengan model ini menuntut siswa untuk belajar dengan pengalaman secara langsung. Belajar berdasarkan pengalaman atau melakukan, akan menstimulus dan menghubungkan berbagai kemungkinan jawaban atas masalah kehidupan yang terjadi di masa depan (Dewey, 2001). Belajar dengan pengalaman akan membawa peserta didik pada sebuah perubahan diri dan cara merespons lingkungan.

Penerapan model pembelajaran $C \& C$ senada dengan tujuan pembelajaran IPS. Pembelajaran IPS di Indonesia berperan untuk memberi pemahaman kepada peserta didik berkaitan dengan empat hal yaitu, pertama tentang konsep-konsep kehidupan masyarakat dan lingkungannya. Kedua, komitmen dan kesadaran terhadap nilai-nilai sosial dan kemanusiaan. Ketiga, kemampuan berpikir rasional, kritis, rasa ingin tahu, memecahkan masalah, dan keterampilan dalam kehidupan sosial. Keempat, adalah kemampuan berkelompok dan berkompetisi baik di tingkat lokal, nasional maupun global dalam keragaman budaya.

Keterbatasan model $C \& C$ antara lain yaitu, masih diterapkan terbatas pada peserta didik kelas VII SMP dan materi IPS. Penerapan model ini juga membutuhkan waktu bagi guru untuk mempersiapkan bahan olahan yang mendukung pembelajaran. Pada awal penerapannya, guru harus mampu mengelola waktu sebaik mungkin. Selain itu, perlunya pemahaman konsep dan teori serta sumber belajar akan membantu maksimalnya proses pembelajaran.

Solusi yang dilakukan untuk meminimalisasi kelemahan-kelemahan model ini antara lain; 1) guru mempersiapkan bahan olahan siap pakai, sehingga peserta didik tidak banyak kehilangan waktu untuk gunting 
menggunting; 2) guru harus bertindak sebagai fasilitator dan motivator dengan memberikan arahan setiap kelompok pada proses pembelajaran; dan 3) penggunaan media pembelajaran IT sangat berperan penting dalam penjelasan konsep atau teori. Selain itu, uji coba pada penerapan materi atau mata pelajaran selain IPS, masih perlu diterapkan untuk mengetahui keunggulan lain model ini.

\section{SIMPULAN}

Produk pengembangan $C \& C$ ini dapat dijadikan salah satu alternatif dalam pembelajaran untuk meningkatkan aktivitas belajar IPS. Akan tetapi, guru harus memperhatikan kesiapan bahan olahan dan pengaturan tempat duduk peserta didik agar pembelajaran maksimal. Pengaturan kelas dan pembelajaran secara tradisional sudah selayaknya dihindari sebagai rutinitas. Sekolah harus mempunyai kebijakan yang mendukung pembelajaran aktif, kreatif, efektif, dan menyenangkan. Selain itu, peneliti lanjutan dapat menerapkan pengembangan model pembelajaran $C \& C$ pada materi atau mata pelajaran yang berbeda. Selain itu, peneliti lanjutan juga dapat mengujicobakan pengaruh penerapan model ini dengan variabel lain, seperti halnya hasil belajar, keterampilan komunikasi, atau kemampuan berpikir kritis.

\section{UCAPAN TERIMA KASIH}

Penulis mengucapkan terima kasih kepada para informan yang terlibat dalam penelitian ini, terutama para siswa SMP N 3
Yosowilangun, Kab. Lumajang, Prov. Jawa Timur sehingga penelitian ini dapat berjalan dengan baik. Selain itu kami ucapkan terima kasih kepada pihak-pihak yang turut membantu support dana sehingga penelitian ini dapat berjalan dengan lancar. Terima kasih kepada redaksi yang telah mempublikasikan artikel hasil penelitian ini.

\section{DAFTAR PUSTAKA}

Ariyanti, A., Wahyono, H., \& Haryono, A. (2016). Model pembelajaran ekonomi MICMAC: rancangan dan pengembangan. In National Conference on Economic Education.

Asmani, J. M. (2013). Tips aplikasi PAKEM (Pembelajaran Aktif, Kreatif, Efektif, dan Menyenangkan). Yogyakarta: Diva Press.

Barkley, E. F. (2009). Student engagement techniques: a handbook for college faculty. San Francisco, CA: Jossey-Bass.

Dewey, J. (2001). Democracy and education: a Penn state electronic classics series publication. Pennsylvania: The Pennsylvania State University.

Dewi, S., \& Amirudin, A. (2016). Penerapan model pembelajaran problem based learning untuk meningkatkan keaktifan dan keterampilan sosial siswa kelas V SDN Tangkil 01 Wlingi. Jurnal Pendidikan: Teori , Penelitian, dan Pengembangan, 1(3), 281-288.

Gall, M. D., Gall, J. P., \& Borg, W. R. (2003). Educational research: an introduction 
(Seventh Ed). Boston: Longman Publishing.

Hariyono. (1995). Mempelajari sejarah secara efektif. Jakarta: PT. Dunia Pustaka Jaya.

Mayangsari, D. (2014). Peningkatan kemampuan membaca permulaan kelas 1 SD Mardi Putera Surabaya dengan menggunakan Pakem (Pembelajaran yang Aktif, Kreatif, Efektif, dan Menyenangkan). MODELING: Jurnal Program Studi PGMI, 1(1), 61-68.

Nurseto, T. (2009). Pelaksanaan pembelajaran dengan pendekatan aktif learning dalam pelajaran Ekonomi pada SMU negeri di Yogyakarta. Jurnal Ekonomi \& Pendidikan, 6(2).

Saraswati, N. M. D., Marhaeni, A. A. I. N., \& Natajaya, I. N. (2015). Pengaruh model PAKEM berbantuan media gambar terhadap hasil belajar IPS pada siswa kelas VI SD 4 Tonja dengan kovariabel motivasi belajar siswa. e-Journal Program Pascasarjana Universitas Pendidikan Ganesha, 5(1), 1-10.

Schneider, D., Adler, S. A., Beery, R., Ladson-Billings, G., Fernekes, W. R., Hartoonian, M., ... Tevis, C. (1994). Expectations of excellence curriculum standards for social studies. Bulletin 89. Washington: National Councils for the Social Studies.
https://doi.org/ED419696

Slameto. (2013). Belajar \& faktor-faktor yang mempengaruhinya (Edisi Revi). Jakarta: Rineka Cipta.

Sugiyono. (2012). Metode penelitian kuantitatif kualitatif dan $R \& D$. Bandung: Alfabeta.

Waty, S., Rustini, T., \& Sundari, N. (2015). Pendekatan saintifik untuk meningkatkan kemampuan komunikasi kolaboratif siswa dalam pembelajaran IPS Di Kelas IV SD. Jurnal PGSD Kampus Cibiru, 3(2). 